\title{
Catheter Device
}

National Cancer Institute

\section{Source}

National Cancer Institute. Catheter Device. NCI Thesaurus. Code C50344.

A flexible tube designed to transfer fluids into or out of the body. 